\title{
$\varlimsup_{\text {HEINONLINE }}$
}

Content downloaded/printed from

HeinOnline

Tue Aug 6 06:50:38 2019

Citations:

Bluebook 20th ed.

Noelle Higgins, Advancing the Rights of Minorities and Indigenous Peoples: Getting un

Attention via the Universal Periodic Review, 32 NETH. Q. HUM. RTS. 379, 407 (2014).

APA 6th ed.

Higgins, N. (2014). Advancing the rights of minorities and indigenous peoples: Getting un attention via the universal periodic review. Netherlands Quarterly of Human Rights, 32(4), 379-407.

Chicago 7th ed.

Noelle Higgins, "Advancing the Rights of Minorities and Indigenous Peoples: Getting un Attention via the Universal Periodic Review," Netherlands Quarterly of Human Rights 32, no. 4 (2014): 379-407

McGill Guide 9th ed.

Noelle Higgins, "Advancing the Rights of Minorities and Indigenous Peoples: Getting un Attention via the Universal Periodic Review" [2014] 32:4 Nethl QHR 379.

MLA 8th ed.

Higgins, Noelle. "Advancing the Rights of Minorities and Indigenous Peoples: Getting un Attention via the Universal Periodic Review." Netherlands Quarterly of Human Rights, vol. 32, no. 4, 2014, pp. 379-407. HeinOnline.

OSCOLA 4th ed.

Noelle Higgins, 'Advancing the Rights of Minorities and Indigenous Peoples: Getting un Attention via the Universal Periodic Review' (2014) 32 NETH Q HUM RTS 379

-- Your use of this HeinOnline PDF indicates your acceptance of HeinOnline's Terms and Conditions of the license agreement availablehatps://heinonline.org/HOL/License

-- The search text of this PDF is generated from uncorrected OCR text.

-- To obtain permission to use this article beyond the scope of your license, please use: Copyright Information

Use QR Code reader to send PDF to your smartphone or tablet device

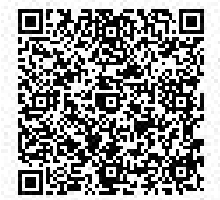




\title{
ADVANCING THE RIGHTS OF MINORITIES AND INDIGENOUS PEOPLES: GETTING UN ATTENTION VIA THE UNIVERSAL PERIODIC REVIEW
}

\author{
Noelle Higgins*
}

\begin{abstract}
Having been neglected by the Universal Declaration of Human Rights (UDHR), ${ }^{1}$ minority rights, and even more so, the rights of indigenous peoples, have developed in quite an ad hoc and indolent manner. The rights of minorities were recognised in Article 27 of the International Covenant on Civil and Political Rights (ICCPR $)^{2}$ in 1966, but as yet no binding UN instrument on minorities exists. Indigenous peoples fared worse under the UN system as their rights, apart from labour rights, ${ }^{3}$ were not codified in a legal instrument until the adoption of the UN Declaration on the Rights of Indigenous Peoples (UNDRIP $)^{4}$ in 2007. Over the years a complex framework of mechanisms was established within the UN to support the rights of these groups, ${ }^{5}$ but their concerns and entitlements were still sidelined to an extent due to the lack of binding instruments and the absence of comprehensive and compulsory State reporting requirements on these issues. However, in 2007 the newly created Human Rights Council developed a novel method of overseeing the implementation of universal human rights standards in the form of the Universal Periodic Review (UPR). The UPR allows for discussion on all human rights issues and is not bound
\end{abstract}

* Senior Lecturer, Department of Law, Maynooth University, Ireland.

1 Universal Declaration of Human Rights (adopted 10 December 1948) UNGA Res 217 A(III) (UDHR).

2 International Covenant on Civil and Political Rights (adopted 16 December 1966) 999 UNTS 171 (ICCPR).

3 The International Labour Organisation has adopted a number of instruments on the rights of indigenous peoples in a labour context, including the Indigenous and Tribal Populations Convention, 1957 (No. 107) and the Indigenous and Tribal Peoples Convention, 1989 (No 169), 72 ILO Official Bull. 59 .

4 United Nations Declaration on the Rights of Indigenous Peoples (adopted 13 September 2007) GA Res 61/295, UN Doc A/RES/47/1 (UNDRIP).

5 In relation to the institutional frameworks on minorities and indigenous peoples, see generally $\mathrm{P}$. Thornberry, International Law and the Rights of Minorities (Clarendon Press 1991); G. Pentassuglia, Minorities in International Law (Council of Europe Publishing 2002) and R. Morgan, Transforming Law and Institution. Indigenous Peoples, the United Nations and Human Rights (Ashgate 2011). 
by the subject matter limitations of the UN treaty body regime, thus encompassing minority rights and indigenous peoples' rights within its rubric. This article seeks to analyse how the rights of minorities and indigenous peoples were dealt with during the first cycle of the UPR and to assess the impact of this mechanism on these rights.

Keywords: Human Rights Council; indigenous peoples' rights; minority rights; universal periodic review

Violations of minority rights constitute today a wide-scale problem, affecting all regions of the world, with multiple manifestations ranging from attacks on religious minorities to systematic exclusion of minorities from decision making in economic and public life, and contributing to statelessness and other serious human rights challenges around the world.

These violations not only undermine human rights and sustainable development, but also fuel insecurity and conflict.

(Address by Ms. Kyung-wha Kang, United Nations Deputy High Commissioner for Human Rights at the $19^{\text {th }}$ Session of the Human Rights Council, 13 March, 2012)

\section{INTRODUCTION}

Despite the vast problems facing the world's minorities and indigenous peoples, as highlighted in the above quote, no universal binding instruments exists to protect them. The omission of any reference to the rights of minorities or indigenous peoples in the Universal Declaration of Human Rights (UDHR) in 1948 portended a bleak future for the protection of these groups within the $\mathrm{UN}$ system. The rights of national minorities in the fields of language, ethnicity and religion had up to that point been protected under the League of Nations regime, ${ }^{6}$ and the rights of indigenous peoples, in the limited context of labour rights, had been dealt with by the International Labour Organisation (ILO). ${ }^{7}$ However, when the UN was created, there was a divergence of ideas as to if, and indeed how, the rights of non-majority groups should be dealt with within its framework. ${ }^{8}$ While

$6 \quad$ For a discussion of the League of Nation system pertaining to minorities, see Thornberry (n 5) at $38-54$.

7 The ILO first began work on the issue of indigenous peoples in 1921 when it undertook studies on the working conditions of indigenous workers. It subsequently adopted a number of legal instruments on indigenous labour, including the Indigenous and Tribal Populations Convention 1957 (No 107) and the Indigenous and Tribal Peoples Convention, 1989 (No 169). Convention No 107 was ratified by 27 countries but it was criticised for its integrationist approach to indigenous people and a new Convention (No 169) was drafted with the input from indigenous groups and adopted in 1989. Convention No 107 is no longer open for ratification, but it is still in force for the 18 States which ratified it. Convention No 169 has been ratified by 20 States. For a discussion of these instruments see Morgan (n 5) at 7-10.

8 Thornberry states: 'At the San Francisco Conference, the high level of interest in human rights did not provoke proposals for the protection of minorities, though the Covenant of the League did not mention them either. Whereas the League supplemented its founding text with a series of minority agreements, this did not occur at the United Nations where a different psychology prevailed'Thornberry (n 5) at 118. 
most European States, having had the benefit of experience from the League of Nations system, ${ }^{9}$ were in favour of including protection for minority groups within the UDHR framework, Latin American countries in particular opposed such a proposition. This was an unsurprising stance, given the extant South American governmental assimilationist policies and laws regarding indigenous populations, ${ }^{10}$ which could potentially fall within the protective remit of a UN minority rights regime. The lack of a common ground on the question of minorities and indigenous peoples led to their omission from the UDHR, ${ }^{11}$ with only a scant reference to the protection of generic cultural rights in Article 27.12 The minorities issue was then handed over to the Subcommission on Prevention of Discrimination and Protection of Minorities to decipher, ${ }^{13}$ while the rights of indigenous peoples remained within the labour-focused rubric of the ILO.

While recommendations were made that a specific instrument on minority rights should be drafted under the auspices of the $\mathrm{UN},{ }^{14}$ the political will to transform such a recommendation into a reality was lacking. Eventually, minority rights found a home in the UN system through the insertion of Article 27 into the International Covenant on Civil and Political Rights (ICCPR), which was adopted in 1966. This rather tame provision states that

[i]n those States in which ethnic, religious or linguistic minorities exist, persons belonging to such minorities shall not be denied the right, in community with the other members of their group, to enjoy their own culture, to profess and practise their own religion, or to use their own language.'. 15

It is to be noted that this right applies to members of minority groups and is not a collective right. Indeed, this provision 'may be described as rights of individuals

$9 \quad$ See H. Rosting, 'The Protection of Minorities by the League of Nations' (1923) 17(4) American Journal of International Law 641; C. Fink, 'The League of Nations and the Minorities Question' (1995) 57(4) World Affairs 197; Pentassuglia (n 5). See also Thornberry's work on the history of the protection of minority and indigenous groups (n 5) and P. Thornberry, Indigenous Peoples and Human Rights (Manchester University Press 2003).

10 According to Pentassuglia, "[t]he "new" States from North and South America favoured "melting pot" and assimilation" (n 5) at 30.

11 Proposals for a UDHR minority provision had been prepared by the Secretariat, the Drafting Committee of the Commission on Human Rights and the Subcommission on Prevention of Discrimination and Protection of Minorities but were met with opposition. Additional proposals were submitted by the Soviet Union, Yugoslavia and Denmark to the General Assembly but these were also opposed. See above.

12 Article 27 of the UDHR States: "(1) Everyone has the right freely to participate in the cultural life of the community, to enjoy the arts and to share in scientific advancement and its benefits. (2) Everyone has the right to the protection of the moral and material interests resulting from any scientific, literary or artistic production of which he is the author."

13 In UNGA Res 217 A (111) of 1948, the General Assembly referred the matter of minorities to ECOSOC, requesting that a thorough study of minority rights issues be undertaken.

14 See Pentassuglia (n 5) at 30.

15 Article 27 International Covenant on Civil and Political Rights, UNGA Res 2200A (XXI). 
premised on the existence of a community, or as individual rights stressing the aspect of their communal exercise'. ${ }^{16}$ However, the provision still protects groups to an extent. In Lubicon Lake Band, the Human Rights Committee stated that the rights which are protected under Article 27 'include the right of persons, in community with others, to engage in economic and social activities which are part of the culture of the community to which they belong'l7 and that it had 'no objection to a group of individuals, who claim to be similarly affected, collectively to submit a communication about alleged breaches of the Covenant'. ${ }^{18}$ Therefore, while the right applies to individuals, the community aspect of Article 27 has been regarded as a central consideration when interpreting the provision. ${ }^{19}$

The inclusion of this provision in the ICCPR precipitated a UN study on the issues of minorities, ${ }^{20}$ which sought to clarify the application of Article 27, but did not lead to the creation of a binding instrument on the issue. The UN also adopted the non-binding Declaration on the Rights of Persons Belonging to National or Ethnic, Religious and Linguistic Minorities ${ }^{21}$ in 1992. Additionally, it set up various bodies within its framework to address minority issues in different forms, ${ }^{22}$ for example, the Sub-Commission on Prevention of Discrimination and Protection of Minorities, the UN Working Group on Minorities, and the Minority Rights Forum. ${ }^{23}$ In addition, minority rights are discussed in the reporting procedures of some UN treaty bodies, particularly with regard to the ICCPR, the International Covenant on Social, Economic and Cultural Rights (ICESCR) and the International Convention on the Elimination of All Forms of Racial Discrimination (ICERD). Some State reports to these treaty bodies are permeated with references to minorities and / or indigenous peoples. For example, the most recent State report from New Zealand on the ICCPR to the Human Rights Committee ${ }^{24}$ is replete with references to the Māori population and discusses most issues of importance relating to this group, not just in the report

16 Pentassuglia (n 5) at 100.

17 Bernard Ominayak. Chief of the Lubicon Lake Band v Canada (1990) Communication No. 167/1984, Views of 26 March 1990, para 32(2).

18 Ibid at para 32(1).

19 See Pentassuglia (n 5) at 100-102.

20 The Sub-Commission on Prevention of Discrimination and Protection of Minorities, via its Special Rapporteur, Francesco Capotorti, undertook a study on the rights of people belonging to ethnic, religious and linguistic minorities between 1971 and 1978. The aim of this study was to evaluate the application of the rights enshrined in Art. 27 of the ICCPR. Francesco Capotorti, 'Study on the Rights of Persons Belonging to Ethnic, Religious and Linguistic Minorities' UN Doc E/CN.4/ Sub.2/384/Rev.1, U.N. Sales No E.78.XIV.1 (1979).

21 UN Doc A/RES/47/135.

22 The UN dealt with some area-specific minority issues on an ad hoc basis, for example, the situations in Cyprus and South Tyrol in Switzerland, but they did not formulate a specific policy or framework in relation to minority rights as part of these discussions. See Pentassuglia (n 5) at 31-32.

23 For a discussion of these bodies, see A. Eide. 'Introduction: Mechanisms for Supervision and Remedial Action' in: M. Weller. (ed), Universal Minority Rights (Oxford University Press 2007).

24 HRC, 'Fifth Periodic Report of States Parties, New Zealand' (18 February 2008) UN Doc CCPR/C/ $\mathrm{NZL} / 5$. 
under Article 27 of the ICCPR but throughout, and mentions areas such as education, health, land claims, broadcasting, and an enhanced relationship between the Māori population and the Crown amongst others. However, other States provide much less information on non-majority groups, for example France. ${ }^{25}$ Other States still have not ratified treaties under which they can report on the state of minorities within their jurisdiction, for example the US. Thus, gaps and a sense of non-universality exist in relation to the present treaty body system. In addition to the treaty body system, however, UN Special Procedures can deal with minority rights issues to varying extents, for instance the Independent Expert on Minority Issues ${ }^{26}$ and Special Rapporteur on contemporary forms of racism, racial discrimination, xenophobia and related intolerance, ${ }^{27}$ to name but two. Nevertheless, minority issues have not found a central place in the treaty body system and remain, to a significant extent, at the periphery of the UN regime. ${ }^{28}$ Indeed, Castellino comments that, in spite of the establishment of a sophisticated human rights system under the UN, the regime of minority rights protection was actually stronger under pre-UN minority systems. ${ }^{29}$

While the UN provisions dealing with minorities can also potentially apply to indigenous peoples, the distinctiveness of these peoples and their concerns is clear and, thus, a separate regime is needed for their protection. However, if one agrees with Tom Hadden's observation that ' $[\mathrm{m}]$ inority protection has always been the poor relation in the human rights family, ${ }^{30}$ then indigenous rights could only be deemed to be a long lost relative. It took a long time for the international community to take account of the rights of indigenous peoples. Despite early efforts on the part of indigenous leaders to

25 See HRC, 'Fifth Periodic Report of States Parties, France' (31 January 2013) UN Doc CCPR/C/ FRA/5. France submits that it has no minorities and has made a reservation to Article 27 of the ICCPR.

26 See HRC Res 79 'Rights of Persons Belonging to National or Ethnic, Religious and Linguistic Minorities' (2005).

$27 \quad$ HRC Res 20 (1993).

28 It should be noted that a handful of UN instruments focus peripherally on minorities, including the UN Convention on the Prevention and Punishment of the Crime of Genocide, adopted by Resolution 260 (III) A of the UN General Assembly on 9 December 1948, which is applicable to minority groups when the very existence of the group is threatened, if that group constitutes a national, ethnical, racial or religious group (art 2). See D. Lisson, "Defining "National Group" in the Genocide Convention, A Case Study of Timor Leste' (2007-2008) 60 Stanford Law Review 1459. In addition, reference was made to minority rights in the UNESCO Convention Against Discrimination in Education, adopted by the General Conference at its eleventh session, Paris (14 December 1960) in article 5(1)(c) and in article 30 of the UN Convention on the Rights of the Child (adopted 20 November 1989, entered into force 2 September 1990) 1577 UNTS 3 which also mentions indigenous children. Furthermore, Part II.B.2 of the Declaration and Programme of Action of the World Conference on Human Rights (1993) UN Doc A/CONF.157/23 also reaffirmed the right of persons belonging to ethnic, linguistic or religious minorities to enjoy their culture, to profess their religion and to use their language in private or public without discrimination.

29 J. Castellino, 'The Protection of Minorities and Indigenous Peoples in International Law: A Comparative Temporal Analysis' (2010) 17 International Journal on Minority and Group Rights 393, 393.

30 T. Hadden, 'The United Nations Working Group on Minorities' (2007) 14 International Journal on Minority and Groups Rights 285, 285. 
connect with international organisations, as when Haudenosaunee Chief Deskaheh ${ }^{31}$ travelled from Canada to Geneva in 1923 in an attempt to engage with the League of Nations, ${ }^{32}$ the issue of indigenous rights was not fully appreciated by the international community until recently. While the ILO created an early framework on the rights of indigenous peoples, this was focused on labour rights only, and was assimilationist in nature. ${ }^{33}$ The issue of indigenous peoples did not feature on the UN agenda to a significant extent until 1982 when the Working Group on Indigenous Populations (WGIP) ${ }^{34}$ of the Sub-Commission on the Promotion and Protection of Human Rights (then called Sub-Commission on Prevention of Discrimination and Protection of Minorities) was established by a decision of the UN Economic and Social Council. In recent years, additional attention has attached to the rights of indigenous peoples, especially since the hard won adoption of the United Nations Declaration on the Rights of Indigenous Peoples (UNDRIP) in 2007.35 Similar to the approach taken to the issue of minorities, the UN has also set up a number of bodies to promote the rights of indigenous peoples within its framework, including the Permanent Forum on Indigenous Issues, the Special Rapporteur on the Rights of Indigenous Peoples, the Special Rapporteur in the field of Cultural Rights, and the Expert Mechanism on the Rights of Indigenous Peoples. ${ }^{36}$

However, the rights of indigenous peoples do not form the basis of a binding UN treaty, ${ }^{37}$ and thus, as with the rights of minorities, mainly fall outside the UN treaty body monitoring system, apart from issues that fall within the purview of Article 27 of the ICCPR as was seen above in the case of the reporting of New Zealand to the Human Rights Committee in relation to the Māori population. ${ }^{38}$ In addition, the rights of indigenous peoples, especially with regard to issues such as non-discrimination,

31 W.T. Singel, 'New Directions for International Law and Indigenous People' (2008-2009) 45 Idaho Law Review 509.

32 The League of Nations did not give Chief Deskaheh the opportunity to speak. The situation was repeated in 1925 when the Maori religious leader T.W. Ratana was also denied access to the League. See N. Tomas, 'Indigenous Peoples and the Maori: The Right to Self-Determination in International Law - From Woe to Go' (2008) 4 New Zealand Law Review 639.

33 See Morgan (n 5) at 7-10.

34 The Working Group on Indigenous Populations was established as a subsidiary organ to the SubCommission on the Promotion and Protection of Human Rights pursuant to ECOSOC Res 1982/34 (1982). It has since been replaced by the Expert Mechanism on the Rights of Indigenous Peoples.

35 See C. Charters, 'Developments in Indigenous Peoples' Rights under International Law and their Domestic Implications' (2005) 21 New Zealand Universities Law Review 511; J. Corntassel, 'Towards a New Partnership? Indigenous Political Mobilization and Co-optation During the First UN Indigenous Decade' (2007) 29(1) Human Rights Quarterly 137.

36 For a discussion of these bodies, see generally Morgan ( $\mathrm{n} 5$ ).

37 For a discussion on the customary status of the rights enshrined in the UNDRIP and other relevant instruments, see M. Barelli, 'The Role of Soft Law in the International Legal System: The Case of the United Nations Declaration on the Rights of Indigenous Peoples' (2009) 58(4) International \& Comparative Law Quarterly 957.

38 It is interesting to note that indigenous peoples have been accepted, without any great discussion or analysis, as a minority for the purposes of Article 27 ICCPR. See Thornberry (n 5) at 210-213. 
children, housing, education, have been dealt with under other UN human rights treaty provisions. ${ }^{39}$ Therefore, while certain limited aspects of the rights of certain minority and indigenous peoples groups find their way before UN bodies in the form of State reports, shadow reports by NGOs, concluding observations and individual complaints, until relatively recently, a complete and comprehensive review of State practice and legislation with regard to the rights of these groups were precluded within the UN system. ${ }^{40}$ While certain states reported on the issues of minorities rights and indigenous peoples as part of their reporting obligations under other core human rights treaties, not all states took this approach, thus leaving issues concerning minority and indigenous peoples somewhat on the margins of UN human rights efforts. ${ }^{41}$

However, with the abolition of the Human Rights Commission and the creation of the Human Rights Council, ${ }^{42}$ the UN possesses new machinery with which it can embrace minority and indigenous rights and move them from the sidelines to a more centralised position within the UN human rights family. This machinery comes in the guise of the Universal Periodic Review (UPR). Under the UPR all Member States of the UN are required to report on their human rights laws and practices every four years to the Human Rights Council. The subject-matter of such reports is not limited, and thus a dedicated space for discussion on minority and indigenous rights has been made at the UN table. In addition, other stakeholders, such as NGOs which represent minorities and indigenous peoples, can play an active role in the UPR process, thus providing these groups with the opportunity to share their concerns with States and to project a strong voice in the UN system. A pertinent question is whether the UPR has, to date, succeeded in mainstreaming the issues of the rights of minorities and indigenous peoples with the UN human rights framework, and indeed, whether the UPR is an appropriate mechanism for this role.

The aim of this article is to analyse how the rights of minority and indigenous groups have featured in the first cycle of the UPR and to assess the potential impact of the new UN mechanism on the future monitoring and the promotion and protection of the rights of these groups. Part II details the establishment and development of the UPR and sets out its modus operandi. Part III provides an analysis of how minority

$39 \quad$ See J. Anaya, Indigenous People in International Law ( $2^{\text {nd }} \mathrm{ed}$, Oxford University Press 2004) 248-258.

40 It should be noted that some minority and indigenous rights issues are routinely considered by States in their reports to some UN treaty bodies, for example the Committee on the Elimination of All Forms of Racial Discrimination However, such studies do not provide a comprehensive and holistic review of the situation of these groups or how State policy and practice impact them. In addition, such reviews are not universal.

41 For a discussion on State practice in relation to human rights treaty bodies, see K. Henrard and R. Dunbar Synergies in Minority Protection (Cambridge University Press 2009).

42 The Human Rights Council replaced the Human Rights Commission by virtue of UNGA Res 60/251 (2006) UN GAOR, 60 ${ }^{\text {th }}$ Sess., 1, UN Doc A/RES/60/251. See generally, B. Ramcharan, The UN Human Rights Council (Routledge 2011); M. Bossuyt 'The New Human Rights Council: A First Appraisal' (2006) 24(4) Netherlands Quarterly of Human Rights 551; N. Schrijver, 'The UN Human Rights Council: A New "Society of the Committed" or Just Old Wine in New Bottles?' (2007) 20(4) Leiden Journal of International Law 809. 
and indigenous rights issues featured during Cycle 1 of the UPR through interactive dialogue between States and through NGO promotion. Part IV interrogates whether the UPR is an effective mechanism for monitoring the rights of minorities and indigenous peoples and to facilitate their promotion and protection. Finally, a number of conclusions as to impact of the UPR process on the rights of minorities and indigenous peoples are submitted in Part V.

\section{THE UPR PROCESS}

After many years of harsh criticism of the UN Human Rights Commission, ${ }^{43}$ the UN created a new human rights institution, the Human Rights Council, in March $2006 .{ }^{44}$ States were eager to re-legitimise the UN human rights framework in the aftermath of the disrepute engendered by the Commission and while there was some disagreement as to how the Council would monitor States' human rights compliance, the decision was made to adopt a peer review approach, which had recently become a popular review choice among inter-governmental organisations. ${ }^{45}$ Abebe posits that 'States and other stakeholders across the spectrum [...] generally embraced the idea of a peer review mechanism where States' human rights performance will be evaluated by the Council in an objective, universal, genuine and non-selective manner' ${ }^{26}$ Thus, the Council was mandated to 'undertake a universal periodic review (UPR), based on objective and reliable information, of the fulfilment by each State of its human rights obligations and commitments in a manner which ensures universality of coverage and equal treatment with respect to all States. ${ }^{47}$ It was foreseen that the review would be a 'cooperative mechanism, based on interactive dialogue, with the full involvement of

43 See H. Boekle 'Western States, the UN Commission on Human Rights and the "1235" procedure: the question of bias revisited' (1995) 13 Netherlands Quarterly of Human Rights 367 and T. Franck, 'Of Gnats and Camels: Is there a Double Standard in the United Nations?' (1984) 78 American Journal of International Law 811. For a discussion of the transition from the Human Rights Commission to the Human Rights Council, see P.G. Lauren, 'To Preserve and Build on its Achievements and to Redress its Shortcomings: The Journey from the Commission on Human Rights to the Human Rights Council' (2007) 29 Human Rights Quarterly 307.

44 UNGA Res 60/251 (15 March 2006) UN Doc A/RES/60/251. With regard to the history and functions of the Human Rights Council, see P.J. Flood, 'The U.N. Human Rights Council: Is its Mandate well-designed?' (2008-2009) 15 ILSA Journal of International and Comparative Law 472 and J. Matiya, 'Repositioning the international human rights protection system: the UN Human Rights Council' (2010) 36(2) Commonwealth Law Bulletin 313.

45 For example, see the African Peer Review Mechanism and the peer-review mechanism of the Development Assistance Committee of the Organisation for Economic Co-operation and Development. See E. McMahon and M. Ascherio, 'A Step Ahead in Promoting Human Rights? The Universal Periodic Review of the UN Human Rights Council' (2012) 18 Global Governance 231.

46 A.M. Abebe, 'Of Shaming and Bargaining: African States and the Universal Periodic Review of the United Nations Human Rights Council’ (2009) 9(1) Human Rights Law Review 1, 2.

47 UNGA Res 60/251 (15 March 2006) UN Doc A/RES/60/251. For a discussion of the UPR see Flood (n 44). 
the country concerned and with consideration given to its capacity-building needs'. ${ }^{4}$ It was also anticipated that the mechanism would complement rather than duplicate the work of UN treaty bodies. ${ }^{49}$ The aim of the UPR was foreseen as the assessment of the 'fulfilment by each State of its human rights obligations and commitments' ${ }^{50}$ The UDHR therefore serves as a basis for the review, in addition to any other human rights treaties which have been ratified by States, applicable international humanitarian law, and any other commitments or pledges concerning human rights issues made by States. ${ }^{51}$ As regards the rights of minorities and indigenous peoples, this means that States can refer to Article 27 of the ICCPR in their reports and their recommendations to States under review which have ratified this instrument. States can also refer to other international and regional instrument which cover these issues, such as ILO Convention No. 169,52 in addition to provisions of other core human rights treaties. In practice, reviews of States with an indigenous population also tend to refer to the UNDRIP. Unlike the treaty body system, in the UPR process States are not overly restricted as to the subject matter of their reports or recommendations, which facilitates a space and forum for a discussion on minority and indigenous peoples' rights.

After much discussion and negotiation, ${ }^{53}$ the UPR mechanism was established through the adoption by the Council of its 'institution-building package' one year after the Human Rights Council's first meeting, ${ }^{54}$ which further clarifies the UPR's aims. While the monitoring and improvement of the human rights practices of all States is the main objective, the UPR process also seeks to assess positive developments within States in the field of human rights and to facilitate the sharing of best practices between States.

There are essentially four elements to the review process, which is facilitated by a troika (three States), picked by lottery. The first phase consists of information gathering, whereby a number of reports are complied, comprising (i) a short report provided by the State under review; (ii) a summary of information from other stakeholders

\footnotetext{
48 UNGA Res $60 / 251$, ibid.

49 Ibid.

50 Ibid.

51 Human Rights Council Res 5/1 (2007) UN Doc A/HRC/Res/5/1 annex at 1.A.1.

52 For example, some regional instruments protect minority and indigenous peoples' rights, including the African Charter on Human and Peoples' Rights (adopted 27 June 1981) OAU Doc CAB/LEG/67/3 rev. 5, 21 ILM 58 (1982). In addition, the Council of Europe has also adopted an instrument dealing specifically with the rights of national minorities, Framework Convention for the Protection of National Minorities 1995, Council of Europe ETS 157, as well as an instrument which has significance for minority languages, the European Charter for Regional or Minority Languages 1998, Council of Europe ETS 148.

53 Different States had varying views on the format they hoped the UPR would take. See the paper prepared by Canada, 'Human Rights Peer Review, Draft Concept and Opinions Paper' (29 April

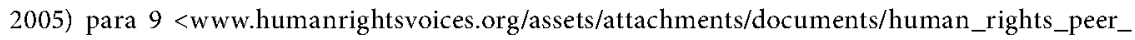
review_canada.pdf $\geq$ accessed 30 April 2013.

54 UNHRC, 'Institution-building of the United Nations Human Rights Council', UNHRC Res 5/1 UN GAOR, $5^{\text {th }}$ Sess., $9^{\text {th }} \mathrm{mtg}$., (2007) 1 UN Doc A/HRC/5/1.
} 
including NGOs which is collated by the Office of the High Commissioner for Human Rights; and (iii) information from independent human rights experts, human rights treaty bodies and other UN entities. This report essentially collates information which has been gathered by other UN bodies on the State under review. This information can consist of State reports under the treaty body mechanisms, for example reports to the Human Rights Committee, as well as information gathered through Special Procedure mechanisms, such as the Special Rapporteur on the Rights of Indigenous Peoples, in addition to other UN machinery such as the Expert Mechanism on the Rights of Indigenous Peoples. Written questions can be forwarded by any member of the UN to the State under review prior to the State giving its oral report.

Second, during a UPR Working Group session (which consists of all 47 members of the Human Rights Council and meets three times a year), each State under review provides an oral report on their human rights practices. This is named the interactive dialogue' phase of the review process between the State under review and all other UN members. States can ask questions and make comments and recommendations on the report submitted by the State under review and the other stakeholder information provided. However, tight time constraints apply to the interactive stage. Each review takes three hours during which time the State under review is given 30 minutes for its presentation, followed by a question and answer session involving all States over two hours. The review concludes with a 30 minute slot during which time the State under review can respond to comments and recommendations that have been made. The time restrictions have manifested in 'many States not being able to speak at all, and diplomats lining up in the pre-dawn darkness to register to speak'. ${ }^{55}$ The tight time constraints have sometimes resulted in a lack of critique of States' human rights records. Sweeney and Saito state that 'a negative trend was established of "friendly States" filling the speakers' list to compliment the State under review' ${ }^{56}$ It should be noted, however, that States which do not get an opportunity to ask a question or make a recommendation to a State under review can submit their comments on the UPR's extranet to which the State under review can respond before the outcome report is adopted.

Third, at the end of the interactive dialogue session the working group completes a report on the dialogue and includes responses made by the State under review to comments made by other States. An additional document is also completed which includes State responses to recommendations made which they have had an opportunity to consider. This is usually in the form of an addendum to the Working Group's report.

Finally, the outcome report, which consists of the Working Group's report in addition to any further comments or pledges made by the State under review, is

\footnotetext{
55 E. McMahon, 'Herding Cats and Sheep: Assessing State and Regional Behavior in the Universal Periodic Review Mechanism of the United Nations Human Rights Council', <www.upr-info.org/ IMG/pdf/McMahon_Herding_Cats_and_Sheeps_July_2010.pdf>, 12 accessed 26 July 2013.

56 G. Sweeney and Y. Saito, 'An NGO assessment of the new mechanisms of the UN Human Rights Council' (2009) 9(2) Human Rights Law Review 203, 210.
} 
adopted during a plenary session of the Human Rights Council. A follow-up to the review is then conducted during the next round of the UPR.

Cycle 1 of the UPR process began in 2008 and ended in 2011. Forty-eight States were reviewed each year in different sessions of the Human Rights Council. The process was fine-tuned before the beginning of Cycle 2 in May 2012 which will be completed in 2016, with some minor changes being made to the modalities, including an increase in the time dedicated to each State's review before the Human Rights Council and the subsequent extension of the timeframe of Cycle 2 from 4 to 4 and a half years. ${ }^{57}$

\section{MINORITIES, INDIGENOUS PEOPLES AND THE UPR: AN EMPIRICAL STUDY}

\subsection{THE UPR: A GENERAL OVERVIEW}

For the purposes of preparing its report on the State under review from the information provided in the UN system and for compiling stakeholders' reports, the Office of the High Commissioner for Human Rights places human rights issues into 14 distinct categories, one of which is 'minorities and indigenous peoples'. This categorisation is quite restrictive and limited but States under review have the option to follow this categorisation or to complete their own report in whichever format they choose. ${ }^{58}$ The NGO UPR Info, on the other hand, takes a broader approach and identifies 54 different issues on which States make recommendations during the UPR process. ${ }^{59}$

During the 12 sessions of the first UPR cycle, a total of 21,353 recommendations were made. ${ }^{60}$ The majority of States engaged with the process, although 39 States did not make any recommendations at all in relation to the reports of other States. ${ }^{61}$ The issues raised in the recommendations dealt with a range of subjects, including those

57 See Resolution 16/21 (15 March 2011) and decision 17/119. A summary of the changes introduced by these instruments is available in UPR Info, 'New UPR Modalities for the Second Cycle' <www.upr-info.org/IMG/pdf/new_upr_modalities_second_cycle.pdf> accessed 30 April 2013.

These categories are: international framework; equality and non-discrimination; right to life, liberty and security of the person; administration of justice, including impunity and the rule of law; right to privacy, marriage and family life; freedom of movement; freedom of religion or belief, expression, association and peaceful assembly, and right to participate in public and political life; right to work and to just and favourable conditions of work; right to social security and to an adequate standard of living; right to education and to participate in the cultural life of the community; minorities and indigenous peoples; migrants, refugees and asylum seekers; internally displaced persons; human rights and counter-terrorism.

59 See 'UPR Info's Statistics of UPR Recommendations, First Cycle'<www.upr-info.org/database/ statistics/index.php?cycle $=1>$ accessed 30 April 2013.

60 See 'UPR Info's Database of UPR recommendations and voluntary pledges' <upr-info.org/ database/> accessed 30 April 2013.

61 The 5 States which were most active in making recommendations in Cycle 1 were: 1. Canada (908), 2. Norway (734), 3. France (703), 4. Spain (697) and 5. Brazil (694). The 5 States which received the most recommendations were: 1. The US (280), 2. Iran (212), 3. Sudan (200), 4. Myanmar (197) and 5. 
covered by UN human rights treaties and those which have yet to be codified in UN treaty form, including the rights of minorities and indigenous peoples. According to UPR Info, the five most common issues raised were the ratification of international human rights instruments $(4,229)$; women's rights $(3,695)$; the rights of the child $(3,451)$; torture and other cruel, inhuman and degrading treatment $(1,748)$ and justice $(1,564) \cdot{ }^{62}$

\subsection{FINDING A PLACE FOR MINORITIES AND INDIGENOUS PEOPLES IN THE UPR}

During the first cycle of the UPR a total of 833 recommendations were made by States on the issue of minorities, ${ }^{63}$ making it the $12^{\text {th }}$ most popular issue on which States made recommendations. ${ }^{64}$ This may seem surprising, given the fact that there is no core human rights treaty dealing with minority rights and States had not heretofore been under an obligation to report to the UN on minority rights issues per se except in the context of Art 27 of the ICCPR ${ }^{65}$ However, 109 States raised the issue of minorities and 131 States received recommendations on the issue, ${ }^{66}$ highlighting that the rights of minorities was a high priority issue for States and other stakeholders. The five States which received the most recommendations on the issue of minorities, from most to least, were: 1. Slovakia, 2. Hungary, 3. Croatia, 4. Bulgaria, and 5. Italy. The five States which made the most recommendations on the issue of indigenous people were, from most to least: 1 . Austria, 2. Canada, 3. United Kingdom, 4. Finland, and 5. Russian Federation. ${ }^{67}$

Moving on to the issue of indigenous peoples, a total of 385 recommendations were made on this issue during the first cycle of the UPR, positioning it in $33^{\text {rd }}$ place out of the 54 different categories of issues raised. ${ }^{68}$ Eighty-one States raised the issue of indigenous peoples and 55 States received recommendations on this topic. ${ }^{69}$ The

Nepal (193). See 'UPR Info's Database of UPR recommendations and voluntary pledges' <upr-info. org/database/> accessed 30 April 2013.

62 See generally, 'UPR Info's Database of UPR recommendations and voluntary pledges' <upr-info. org/database/> accessed 30 April 2013.

63 See 'Statistics on human rights issues on the UPR recommendations and voluntary pledges, First Cycle' <www.upr-info.org/database/statistics/index_issues.php?fk_issue $=32 \& c y c l e=1>$ accessed 30 April 2013.

64 See 'UPR Info's statistics of UPR recommendations, First Cycle'<www.upr-info.org/database/ statistics/index.php? cycle $=1>$ accessed 30 April 2013.

65 It is noted that minority rights issues were discussed and reported on by various States under the auspices of some UN treaties, for example the UN Convention of the Elimination of All Forms of Racial Discrimination.

'Statistics on human rights issues on the UPR recommendations and voluntary pledges, First Cycle' $<$ www.upr-info.org/database/statistics/index_issues.php?fk_issue $=32 \&$ cycle $=1>$ accessed 30 April 2013.

67 Ibid.

68 'UPR Info's statistics of UPR recommendations, First Cycle'<www.upr-info.org/database/statistics/ index.php?cycle $=1>$ accessed 30 April 2013.

69 Ibid. 
five States which received the most recommendations on this issue were, from most to least: 1. Australia, 2. Chile, 3. Canada, 4. Mexico, and 5. Paraguay. The five States which made the most recommendations on the issue of indigenous people were, from most to least: 1. Norway, 2. Mexico, 3. Bolivia, 4. Austria, and 5. Denmark. ${ }^{70}$ Given the relative newness of this issue on the agenda of the UN, with the UNDRIP being adopted in 2007 just as the Human Rights Council and the UPR were being created, this once again illustrates the prominence of the right of indigenous peoples among States and other stakeholders. There has been a general trend in the interactive dialogue phase with regard to States which have an indigenous population to ask questions and make recommendations on this issue. ${ }^{71}$

\subsubsection{Issues raised concerning minorities during Cycle 1 UPR}

A number of common themes concerning the rights of minorities emerged during the interactive dialogue phase of Cycle 1 , which are identified below, along with examples of the types of recommendations made on these themes:

1. Protection from discrimination. On this issue, Argentina recommended that Albania ensure that all members of ethnic and linguistic minorities, recognised as such or not, should enjoy all social rights and should be protected from any form of discrimination ${ }^{72}$ and Cyprus recommended that Armenia continue to hold awareness-raising campaigns within Armenian society about the rights of national minorities, with the aim of further enhancing tolerance and non-discrimination in all spheres of public life. ${ }^{73}$

2. Domestic legal recognition of the rights of minorities. Nigeria, for example, recommended that Bulgaria enshrine in its Constitution the protection of rights of national and ethnic minorities ${ }^{74}$ and Ecuador recommended that Samoa adopt domestic laws and administrative regulations aimed at eradicating all forms of discrimination against minorities. ${ }^{75}$

3. Education and training of officials and the public with regard to minority groups. With regard to training, the Czech Republic recommended that Albania provide

$70 \quad$ See 'Statistics on human rights issues on the UPR recommendations and voluntary pledges, First Cycle' <www.upr-info.org/database/statistics/index_issues.php?fk_issue=26\&cycle=1 > accessed 30 April 2013.

71 See IWIGA, The Indigenous World 2011 (IWIGA 2011) 515.

72 UNHRC 'Report of the Working Group on the Universal Periodic Review: Albania' UN GAOR, Human Rights Council, $13^{\text {th }}$ Sess., UN Doc A/HRC/13/6 (2010) 18, para. 67.85.

73 UNHRC 'Report of the Working Group on the Universal Periodic Review: Armenia' (2010) UN GAOR, Human Rights Council, 15 ${ }^{\text {th }}$ Sess., UN Doc A/HRC/15/9, 15 para 93.18.

74 UNHRC 'Report of the Working Group on the Universal Periodic Review: Bulgaria' (2011) UN GAOR, Human Rights Council, $16^{\text {th }}$ Sess., UN Doc A/HRC/16/9, 18 para 80.64 .

75 UNHRC 'Report of the Working Group on the Universal Periodic Review: Samoa' (2011) UN GAOR, Human Rights Council, $18^{\text {th }}$ Sess., UN Doc A/HRC/18/14, 19 para 75.31. 
human rights education and training to police officers, correction officers and judicial staff aimed at the protection of women, persons of minority sexual orientation and gender identity and national minorities ${ }^{76}$ and Libya recommended that Belarus continue to raise awareness in the media and deepen understanding of human rights principles and protect and promote different cultures, traditions and religions as a principal factor of stable relations among ethnic groups. ${ }^{77}$

5. Language rights. In respect of language rights Austria recommended that Estonia ensure that adequate status is accorded to minority languages. ${ }^{78}$ On this issue Austria recommended that Armenia ensure that children belonging to all minority groups have equal access to education. ${ }^{79}$

6. Hate speech. With regard to hate speech, Egypt recommended that Austria review and update its anti-hate speech legislation to provide equal protection to all religious minorities ${ }^{80}$ and Malaysia recommended that Bulgaria take more resolute action to prevent and punish perpetrators of racially motivated acts and propaganda that targeted ethnic minorities and foreigners. ${ }^{81}$

7. Collection of information and data on minority groups. A common recommendation made by States throughout the interactive dialogues was that States should collect additional information on minority groups within their territory, for example, the Russian Federation recommended that Austria establish a comprehensive data collection system to better assess the level of discrimination that exists against different minority groups in Austria. ${ }^{82}$

8. Religious rights. With regard to religion, Finland recommended that Egypt guarantee freedom of religion and belief to all groups and minorities. ${ }^{83}$

In addition to these thematic issues, the Roma garnered a lot of attention throughout the UPR process and numerous States made recommendations as to how States which have a Roma minority population should seek to protect and promote their rights. For example, Canada recommended that Albaniafully implement its action plan to improve

76 UNHRC 'Report of the Working Group on the Universal Periodic Review: Albania' (2010) UN GAOR, Human Rights Council, 13 ${ }^{\text {th }}$ Sess., UN Doc A/HRC/13/6, 12 para 67.19.

77 UNHRC 'Report of the Working Group on the Universal Periodic Review: Belarus' (2010) UN GAOR, Human Rights Council, $15^{\text {th }}$ Sess., UN Doc A/HRC/15/16, 18 para 97.51.

78 UNHRC 'Report of the Working Group on the Universal Periodic Review: Estonia' (2011) UN GAOR, Human Rights Council, $17^{\text {th }}$ Sess., UN Doc A/HRC/17/17, 19 para 80.20.

79 UNHRC 'Report of the Working Group on the Universal Periodic Review: Armenia' (2010) UN GAOR, Human Rights Council, 15 ${ }^{\text {th }}$ Sess., UN Doc A/HRC/15/9, 18 para 93.47.

80 UNHRC 'Report of the Working Group on the Universal Periodic Review: Austria' (2011) UN GAOR, Human Rights Council, $17^{\text {th }}$ Sess., UN Doc A/HRC/17/8, 17 para 92.69.

81 UNHRC 'Report of the Working Group on the Universal Periodic Review: Bulgaria' (2011) UN GAOR, Human Rights Council, $16^{\text {th }}$ Sess., UN Doc A/HRC/16/9, 16 para 80.41.

82 UNHRC 'Report of the Working Group on the Universal Periodic Review: Austria' (2010) UN GAOR, Human Rights Council, 17 th Sess., UN Doc A/HRC/17/8, 21 para 93.29.

83 UNHRC 'Report of the Working Group on the Universal Periodic Review: Egypt' (2010) UN GAOR, Human Rights Council, $14^{\text {th }}$ Sess., UN Doc A/HRC/14/17, 18 para 95.96. 
the living conditions of minorities, especially Roma. ${ }^{84} \mathrm{~A}$ number of States also made recommendations to Ireland regarding the Travelling Community, including Chile, which recommended that Ireland strengthen measures to improve the representation, education and protection of Travellers ${ }^{85}$ and Slovakia, which recommended that Ireland recognise Travellers as an official minority, a recommendation that was rejected by Ireland. ${ }^{86}$

\subsubsection{Issues raised concerning indigenous peoples during Cycle 1 UPR}

The main issues which arose in the interactive dialogue phase of the UPR on the issue of indigenous peoples during Cycle 1, along with some examples, are detailed below:

1. Domestic and / or constitutional recognition of indigenous peoples. On this issue Slovenia recommended to Bolivia that it continue with efforts to implement the provisions of its new Constitution in order to ensure that indigenous peoples fully enjoy their rights ${ }^{87}$ and Denmark recommended to Chile that it complete the process of constitutional recognition of the indigenous populations. ${ }^{88}$

2. The ratification and / or implementation of ILO Convention No 169. This recommendation was made to a number of States, including Australia, ${ }^{89}$ Finland ${ }^{90}$ and New Zealand. ${ }^{91}$

3. The adoption and / or implementation of the UNDRIP. This was a similarly common recommendation made to numerous States, including New Zealand, ${ }^{92}$ Canada ${ }^{93}$ and the United States. ${ }^{94}$

5. Participation of indigenous peoplesin decision making and publicaffairs. Regarding this topic, Slovenia recommended to Australia that it consult with Aboriginal and

84 UNHRC 'Report of the Working Group on the Universal Periodic Review: Albania' (2010) UN GAOR, Human Rights Council, $13^{\text {th }}$ Sess., UN Doc A/HRC/13/6, 18 para 67.80.

85 UNHRC 'Report of the Working Group on the Universal Periodic Review: Ireland' (2011) UN GAOR, Human Rights Council, $19^{\text {th }}$ Sess., UN Doc A/HRC/19/9, 16 para 106.30.

86 Ibid at 20 para 107.33 .

87 UNHRC 'Report of the Working Group on the Universal Periodic Review: Bolivia' (2010) UN GAOR, Human Rights Council, $14^{\text {th }}$ Sess., UN Doc A/HRC/14/7, 18 para 98.45.

88 UNHRC 'Report of the Working Group on the Universal Periodic Review: Chile' (2009) UN GAOR, Human Rights Council, $12^{\text {th }}$ Sess., UN Doc A/HRC/12/10, 20 para 96.57.

89 UNHRC 'Report of the Working Group on the Universal Periodic Review: Australia' (2011) UN GAOR, Human Rights Council, $17^{\text {th }}$ Sess., UN Doc A/HRC/17/10), 13 para 86.11.

90 UNHRC 'Report of the Working Group on the Universal Periodic Review: Finland' (2008) UN GAOR, Human Rights Council, $8^{\text {th }}$ Sess., UN Doc A/HRC/8/24, 15 para 50.5 .

91 UNHRC 'Report of the Working Group on the Universal Periodic Review: New Zealand' (2009) UN GAOR, Human Rights Council, $12^{\text {th }}$ Sess., UN Doc A/HRC/12/8, 16 para 81.5.

$92 \quad$ Ibid at 17 para 81.8 .

93 UNHRC 'Report of the Working Group on the Universal Periodic Review: Canada' (2009) UN GAOR, Human Rights Council, $11^{\text {th }}$ Sess., UN Doc A/HRC/11/17, 20 para 86.45.

94 UNHRC 'Report of the Working Group on the Universal Periodic Review: United States of America' (2011) UN GAOR, Human Rights Council, 16 $6^{\text {th }}$ Sess., UN Doc A/HRC/16/11, 13 para 92.1. 
Torres Strait Islander people and take into consideration the guidelines proposed by the Australian Human Rights Commission before considering suspension of the Racial Discrimination Act for any future intervention affecting the Aboriginal and Torres Strait Islander people. ${ }^{95}$

6. Land rights. A number of recommendations focused on the issue of indigenous lands, including, for example, Slovenia's recommendation to Belize to protect Mayan customary property rights in accordance with Mayan customary laws and land tenure practices in consultation with affected Mayan people. ${ }^{96}$

7. Education / training as regards the culture and language of indigenous people for people in official positions. In this regard, Austria recommended to Australia that it enhance the contacts and communication between Aboriginal and Torres Strait Islander communities and law enforcement officials and enhance the training of those officials with respect to cultural specificities of these communities. ${ }^{97}$

8. Engagement with other UN bodies on the issue of indigenous rights. On this issue, for example, Jordan recommended that Canada effectively implement UN treaty bodies' recommendations on indigenous peoples. ${ }^{98}$

\section{IS THE UPR AN EFFECTIVE MECHANISM FOR ADVANCING THE RIGHTS OF MINORITIES AND INDIGENOUS PEOPLES?}

The jury is as yet out as to the impact of the UPR as a tool to monitor State compliance with international human rights standards. Given that we are just mid-way through the second cycle it is understandable and justifiable that a concrete, definitive determination on its effectiveness has not yet been made. However, a number of academic and NGO commentators have undertaken some early analysis on the UPR's efficacy and some preliminary observations on the appropriateness of the UPR as a mechanism for advancing the rights of minorities and indigenous peoples can be made.

\subsection{CRITIQUE OF THE UPR}

Early on, the potential of the UPR was trumpeted by UN officials, who unsurprisingly sang its praises in harmony. For example, at the fourth session of the Human Rights Council

95 UNHRC 'Report of the Working Group on the Universal Periodic Review: Australia' (2011) UN GAOR, Human Rights Council, $17^{\text {th }}$ Sess., UN Doc A/HRC/17/10, 14 para 86.26.

96 UNHRC 'Report of the Working Group on the Universal Periodic Review: Belize' (2009) UN GAOR, Human Rights Council, $12^{\text {th }}$ Sess., UN Doc A/HRC/12/4, 16 para 68.9.

97 UNHRC 'Report of the Working Group on the Universal Periodic Review: Australia' (2011) UN GAOR, Human Rights Council, $17^{\text {th }}$ Sess., UN Doc A/HRC/17/10, 19 para 86.95.

98 UNHRC 'Report of the Working Group on the Universal Periodic Review: Canada' (2009) UN GAOR, Human Rights Council, $11^{\text {th }}$ Sess., UN Doc A/HRC/11/17, 17 para 86.15. 
in 2007, Ban Ki-moon stated that the UPR had 'great potential to promote and protect human rights in the darkest corners of the world'. ${ }^{99}$ Similarly, in 2008 Louise Arbour, the former UN High Commissioner for Human Rights, stated that the UPR could 'provide a vehicle for scrutiny for the implementation of rights and norms beyond anything ever attempted by the Commission on Human Rights.' ${ }^{100}$ It is unclear, as yet, whether the UPR has lived up to these lofty ambitions and expectations. NGO reports and academics seem divided on the success of the UPR. Some identify a theme of bargaining and block voting within the UPR framework, with States congratulating like-minded States and condemning others. ${ }^{101}$ Abebe comments that $[\mathrm{t}]$ here are ominous signs that the problem of regional block voting, which had seriously afflicted the former Commission, remains a formidable challenge to the Council's decision making process' ${ }^{102} \mathrm{He}$ goes on to state that ' $[r]$ egional alliance is a major force influencing the review process. Groups never issue statements that are critical of one of their own' ${ }^{103}$ This problem of unwarranted mutual praise was also highlighted by UN Watch in a 2009 report which assessed the behaviour of 55 States during the UPR process. The report stated that ' $\mathrm{t}$ ] ragically, a majority of 32 out of 55 countries acted as a mutual praise society, misusing the process in order to legitimize human rights abusers, instead of holding them to account'. 104 If such bias is indeed endemic in the UPR system, then it is unlikely that a full and frank appraisal of the issues facing minority and indigenous groups can be undertaken or that the protection of the rights of these groups will increase.

However, other reviews of the UPR have been more positive, including Frazier's appraisal of the implementation efforts of nine States regarding UPR recommendations. He states that

the UPR has been effective in promoting human rights in the short term. It has helped to highlight serious human rights violations and has done so in a public forum that allows debate to occur on the best way to address those problems. The UPR has also helped to give count ries specific guidance, and individualized, achievable goals to meet in progressing respect for human rights; goals which many countries have met or are in the process of meeting.

However, Frazier is less certain about the long term prospects of the mechanism, stating: '[...] as with many multilateral undertakings, the HRC will require the

99 UN Secretary-General, Ban Ki-moon, 'Address to the $4^{\text {th }}$ session of the UN Human Rights Council' <www.un.org/apps/news/story.asp?NewsID=21834\#.UYD0q6JayPc > accessed 1 May 2013.

100 UN Press Release, 'Address by Louise Arbour, UN High Commissioner for Human Rights on the occasion of the eighth session of the Human Rights Council' (Geneva, 2 June 2008) $<$ www.unhchr.ch/huricane/huricane.nsf/0/06B91 AC08630D980C125745C00304584?opendocume nt $>$ accessed 30 April 2013.

101 See McMahon (n 55).

102 See, for example, Abebe ( $\mathrm{n}$ 46) at 19.

103 Ibid.

104 UN Watch, Mutual Praise Society. Country scorecard and evaluation of the Universal Periodic Review system of the UN Human Rights Council. (2009) Presented at the United Nations Human Rights Council February 62009. 
continued leadership of the major developed nations of the world, and if that falters, we may see the HRC fall apart just as its predecessor the CHR did'. ${ }^{105}$

Other commentaries remain ambivalent or open-minded towards the UPR exercise and wait for history to decide its fate, ${ }^{106}$ but as time passes, the general mood regarding the UPR seems to be one of positivity. ${ }^{107}$ This positivity is engendered and increased through the publication of analyses on the implementation of UPR recommendations, ${ }^{108}$ which illustrate that States have, in the main, considered recommendations made to them by other States during the UPR process and have amended their policies and practices accordingly. ${ }^{109}$ Recommendations made during the interactive dialogue phase of the UPR are often finding their way in various shapes and forms into domestic practice through amendment of domestic laws, ratification of international instruments and changes in governmental policies. ${ }^{110}$ This is very important in the context of the rights of minorities and indigenous groups, who do not have a central role in the UN treaty system. In addition, as already mentioned, recommendations made as part of the UPR in respect of minorities and indigenous peoples can be based on information garnered from treaty bodies via the UN State report as part of the UPR process and indeed, such recommendations can later be taken up by treaty bodies, thus strengthening the focus on, and protection of, these groups within the UN human rights framework.

105 Ibid.

106 See, for example, R. Brett, 'A Curate's Egg' (August 2009) Quaker United Nations Office <www.quno.org/geneva/pdf/humanrights/ACuratesEgg200908.pdf > accessed 3 May 2013.

107 See, for example, Human Rights Watch, 'Curing the Selectivity Syndrome. The 2011 Review of the Human Rights Council' <www.hrw.org/print/reports/2010/06/24/curing-selectivity-syndrome> accessed 1 May 2013 and E.R. McMahon, 'The Universal Periodic Review: A Work in Progress. An Evaluation of the First Cycle of the New UPR Mechanism of the United Nations Human Rights Council' (2012) <www.upr-info.org/IMG/pdf/mcmahon_a_work_in_progress.13.09.2012.pdf > accessed 1 May 2013.

108 See, for example, UPR Info, 'Universal Periodic Review; On the Road to Implementation' (2012) $<$ www.upr-info.org > accessed 3 May 2013. A number of studies have reviewed the UPR from the perspective of children's rights. See also, for example, Children's Rights Information Network, 'Status of Children's Rights in the UPR' (November 2010) <www.crin.org/resources/infoDetail. asp?ID =22015\&flag=repor $\#$ $\forall v>$ accessed 3 May 2013; J. Jolley, 'An Academic Study of the Universal Periodic Review (UPR) from the Perspective of Children's Rights' (2012) <www.upr-info.org/IMG/ pdf/2012_10_james_jolley_upr_perspective_of_children_s_rights.pdf $>$ accessed 2 May 2013; Global Initiative to End All Corporal Punishment of Children, 'Corporal punishment of children in the Universal Periodic Review: Analysis of the first cycle (2008-2011)' (2012) <www.upr-info.org/ IMG/pdf/gieacpc_1st_cycle_analysis.pdf > accessed 01/05/13. On the issue of sexual orientation and the UPR, see F. Cowell and A. Milon, 'Decriminalisation of Sexual Orientation through the Universal Periodic Review’ (2012) 12(2) Human Rights Law Review 352. Other reviews have concentrated on the experience of specific States of the UPR, see, for example, E. Dewhurst and N. Higgins, 'Ireland and the Universal Periodic Review: A Two way Process' (2012) 1 Socio-Legal Studies Review140.

109 See E.R. McMahon (n 107).

110 Details of States' implementation of UPR recommendations are set out in a number of publications. See, for example, UPR Info (n 108). 
In short, it seems that, to date, States are taking the UPR quite seriously. This is also evidenced by the fact that States actively engage in the process and provide reports to the Human Rights Council. The international community may have held its breath for a time in January 2013 when Israel seemed to shun the process by not delivering its second UPR report, ${ }^{111}$ but there was a collective exhalation in March when Israel clarified that it sought a mere postponement of its report and dismissed rumours of UPR repudiation. It was of utmost importance that Israel was welcomed back into the UPR and Human Rights Council fold for the legitimacy of the process and the organisation. To date, this has been the one major State-made blemish on the complexion of the otherwise quite attractive UPR process, ${ }^{112}$ and it should be noted that Israel's request for a postponement was not as a result of dissatisfaction with the UPR process itself, but was rather a product of its feelings towards the Human Rights Council in general. ${ }^{113}$

\subsubsection{Positive impact of the UPR with regard to minorities and indigenous groups}

From a review of Cycle 1 of the UPR some preliminary observations can be made on the impact the UPR has made and / or indeed can potentially make in the future in the context of the promotion and protection of the rights of minorities and indigenous peoples.

First, one of the greatest advantages of the UPR over the UN treaty body system is the universality of the process. Every State in the world is required to undergo a similar review. When it was designed it was envisaged that the UPR would treat every State equally and despite the general inequality of States as regards size, power and resources, Smith is confident that this has been the case. She posits that 'there is evidence of a real attempt to treat every State the same in terms of the process of universal periodic review'.114 Therefore, a comprehensive and universal examination and analysis of the rights of minorities and indigenous peoples could be possible through the UPR, so long as the above-mentioned bias is removed from the process. In order to facilitate this universality the UN has a fund to assist developing countries

111 See P. Greenwood, 'Israel Refuses to Appear before UN Human Rights Review' Telegraph (London, 29 January 2013).

112 Some States have experienced difficulties in engaging with the UPR on schedule or as per the guidelines. For example, Cape Verde did not submit a national report for its first review in 2008 (it subsequently submitted a report for the second UPR cycle in April 2013), but the review still continued, while Haiti's first review was postponed from the eight to the twelfth session due to the earthquake which had devastated the region. South Africa failed to submit its written report on time for its first review and thus took the option of presenting its report orally. It did, however, then distribute a written report during its oral submission.

113 See B. Ravid, 'Israel to negotiate renewal of cooperation with UN Human Rights Council', Haaretz, (7 May $2013<$ www.haaretz.com/news/diplomacy-defense/israel-to-negotiate-renewal-ofcooperation-with-un-human-rights-council.premium-1.519719> accessed 30 April 2013.

114 R.K.M. Smith, "Equality of "Nations Large and Small": Testing the Theory of the Universal Periodic Review in the Asia-Pacific' (2011) 2 Asia-Pacific Journal on Human Rights and the Law 36, 53. 
to attend and participate in the UPR meetings in Geneva. ${ }^{115}$ However, it should be noted that the level at which a State can engage in the interactive dialogue with other States under review can be restricted if States do not have a permanent mission in Switzerland. 116

In addition, another possible advantage of the UPR over other review mechanisms in the context of the rights of minorities and indigenous peoples is its novel peer-review approach. The dialogic approach, as opposed to an adversarial approach, favoured by the UPR can facilitate a more open and honest State report on a broad spectrum of issues, which may not have heretofore garnered adequate consideration at the domestic level, including the rights of minorities and indigenous peoples. ${ }^{117}$ Indeed, States under review may also illustrate a greater receptiveness to recommendations made by other States as a result of the dialogic nature where there is a spirit of cooperation rather than imposition, confrontation and antagonism as regards human rights standards. ${ }^{118}$ States can also learn from past experience of other States with regard to policies and laws concerning minorities and indigenous peoples which may encourage them in their own domestic policy and law-making endeavours. However, States' own political and indeed, financial, concerns will always have to be factored into how they deal with recommendations with regards to their human rights practices, including in relation to minority and indigenous groups.

Third, the UPR has acted as a lightning rod of sorts, and has attracted all of the information within the UN system concerning the rights of minorities and indigenous peoples which has been collected through the various UN mechanisms, into one forum. Thus, information which the UN treaty bodies have gathered through State reports, concluding observations and individual complaints in addition to Special Procedures mechanisms such as the Special Rapporteur on the Rights of Indigenous Peoples, are summarised as part of the UN report on the State under review. These reports are a vital aspect of the UPR process as, in general, they comprehensively detail previous interaction between the State and UN bodies on human rights issues, one category being the rights of minorities and indigenous peoples. They provide an excellent basis for reflection on State practice and policy on these issues. In numerous UPR sessions States making recommendations have referred to the reports of treaty

115 Human Rights Council Res 6/17 'UPR Voluntary Trust Fund' (28 November 2001) UN Doc. A/ $\mathrm{HRC/RES/6/17.}$

116 See Smith (n 114). Smith discusses the financial difficulties faced by smaller States such as Nauru regarding participation in the UPR. She states that 'perhaps consideration should be given to alternative mechanisms for participation: teleconferencing or electronic participation perhaps', at 51.

117 See Cowell and Milon (n 108) at 346, who state: 'While the process gives no guarantee that the recommendations agreed are followed through, the soft law approach can be advantageous when considering issues that are culturally sensitive or controversial, or have not been previously under active consideration in a State's domestic political or constitutional institutions'.

118 Ibid at 352, state that '... the dialogic process can be instrumental in tackling contentious human rights issues...in a way that was not previously possible. By providing a channel for views and strategies, the peer review process allows us to see reform from a different angle and to give it stronger force'. 
bodies and Special Procedures on minority and indigenous groups. For example, with regard to treaty bodies, Germany recommended to Cambodia that it implement a previous recommendation of the Committee on Economic, Social and Cultural Rights to better protect human rights leaders, including indigenous leaders, ${ }^{119}$ and Jordan made a very general recommendation to Canada to implement UN treaty body recommendations as appropriate with regard to indigenous peoples. ${ }^{120}$ Regarding UN Special Procedures, the US recommended to Suriname that it continue to work with the Special Rapporteur on the Rights of Indigenous Peoples ${ }^{121}$ and Canada recommended to Colombia that it follow up on the recommendations made by the Special Rapporteur in 2004. ${ }^{122}$ In addition, as mentioned above, information garnered as part of the UPR process can feed back into the UN treaty body system, whereby monitoring bodies can refer to the recommendations made as part of the UPR in their concluding recommendations. In summary, the UPR has facilitated the focus of additional attention, debate and discussion on issues concerning minorities and indigenous peoples within the UN system.

Fourth, because the information gathered by the UN via the State reports, NGO shadow reports, concluding observations, individual complaints and other mechanisms is limited to certain aspects of the rights of minorities and indigenous peoples, the UPR can provide a 'value added' aspect to the promotion and protection of the rights of these peoples because it facilitates a review of State practice in all spheres. Therefore, a more complete picture of the rights of these groups and the State practice concerning these groups can be ascertained more clearly. As Smith comments, '[c]ommon themes emerge from the interactive dialogue, themes not prevalent in the work of the treaty bodies'. ${ }^{123}$ Therefore, it is submitted that the UPR can provide a more holistic analysis of the rights of minority and indigenous peoples than is possible under the treaty body system. Rather than dealing with specific aspects concerning these groups in limited fields such as non-discrimination as can be done by the CERD, the UPR can facilitate a broader discussion of all issues facing minorities and indigenous peoples in the State under review.

Fifth, and more idealistically, the inbuilt concept of 'lesson-sharing' between States involved in the review process may help States to be more proactive in changing frameworks or instituting policies in relation to minorities and indigenous peoples

119 This recommendation was accepted by the government of Cambodia. See < www.upr-info.org/ database/> accessed 30 April 2013.

120 This recommendation was accepted by the government of Canada. See <www.upr-info.org/ database/> accessed 30 April 2013.

121 This recommendation was accepted by the government of Suriname. See < www.upr-info.org/ database/> accessed 30 April 2013.

122 This recommendation was accepted by the government of Colombia. See < www.upr-info.org/ database/> accessed 30 April 2013.

123 R.K.M. Smith, 'More of the Same or Something Different? Preliminary Observations on the Contribution of Universal Periodic Review with reference to the Chinese Experience' (2011) 10 Chinese Journal of International Law 565, 583. 
once they see how similar frameworks or policies have worked elsewhere. As Smith observes:

... [i]t is apparent that universal periodic review is intended to be something more than a "report card" identifying strengths and weaknesses. Rather there is clear intention on the part of the Council that the process will result in an improvement of the human rights situation generally through sharing good practices, cooperation with other UN mechanism [sic.] (notably the UN special procedures) and the identification of areas in which technical assistance could be provided. This is conducive to the inter-governmental nature of the process and should support the entire UN human rights system. ${ }^{124}$

Another positive feature of the UPR process in the context of indigenous and minority groups is the participation of NGOs and civil society movements which are given the opportunity to contribute to a report on the activities of States. While the process is still State-driven and States alone have the right of audience during the delivery of its report and the interactive dialogue phase, NGOs sill have an important role to play in the procedure. ${ }^{125}$ The NGO role in the UPR process is of vital importance to minority groups and indigenous peoples as, first, these groups are often marginalised in their States and have little or no voice in decision making. Their concerns can be brought to the attention of their governments, the general public and indeed the international community through the work of NGOs as part of the UPR process. Second, because no binding UN instruments exist on the issues of minority rights or indigenous rights, such rights could be sidelined in the UPR process if they are not highlighted by NGOs as States may not necessarily feel the need to comment on these groups during their reviews.

The UPR presents various opportunities for NGOs to participate in the review process, more so than through shadow reports to treaty bodies, which makes it a very valuable mechanism for minorities and indigenous peoples. The importance of NGOs in the UPR process is highlighted by Moss, who observes that:

[s]ome of the most significant opportunities lie not in the proceedings in the Human Rights Council in Geneva, but internally in societies around the world. NGOs can engage in a continuous cycle of advocacy built around UPR: advocating for national consultations, special procedure visits, and ratification of human rights treaties; submitting information

124 See R.K.M. Smith (n 114). Smith also comments that '[s]haring good practices among peers, as well as offering constructive technical assistance and other forms of capacity building, are cornerstones of the process, which is perhaps to be expected given its structure as an intergovernmental process', in R.K.M. Smith, 'To see Themselves as Others see Them: The Five Permanent Members of the Security Council and the Human Rights Council's Universal Periodic Review' (2013) 35 Human Rights Quarterly 1,9.

125 NGOs do not need to have consultative status with the UN as per ECOSOC Res 1996/31 in order to submit information to the Office of the High Commissioner for Human Rights on the State under review. However, only States with consultative status can make a statement during the plenary session of the Human Rights Council where the outcome reports are adopted. 
to treaty monitoring bodies and in the UPR process itself; advocating for the acceptance of recommendations made in UPR and then for implementation of those recommendations. ${ }^{126}$

As part of the UPR process NGOs have the opportunity to influence how States engage with the review mechanism at various stages. First, NGOs can influence States as State reports are being drafted and some States have invited consultations with other stakeholders before the completion of their reports. ${ }^{127}$ In addition, the documents which are submitted by NGOs to the UN for the purposes of the UPR are published on the website of the Office of the High Commissioner for Human Rights on the page for the relevant State, thus facilitating easy access to a body of information on all States. ${ }^{128}$ While these documents are half the length of the States reports, ${ }^{129}$ the reports considered by the Human Rights Council 'do not have a hierarchy, thus distinguishing them from the State report and NGO shadow reports to Treaty Bodies'. ${ }^{30}$

NGOs also have the opportunity to lobby States to make recommendations on particular issues to States under review and indeed to lobby, both at home and in Geneva, States under review to accept recommendations. NGOs with consultative status have the opportunity to speak during the plenary sessions of the Human Rights Council when the outcome reports are adopted. The lobbying role of NGOs can continue through the implementation phase of the UPR where they can lobby States to implement the recommendations which they accepted during the review process and consider some additional recommendations which they did not accept at the time.

While it is appreciated that not every State is open to pressure from NGOs, '[f] or States truly open to improvement, UPR offers an opportunity to get the attention of high-level officials and policy-makers for human rights problems'. ${ }^{131}$ In order the harness the potential of the UPR for the improvement of minority and indigenous peoples' rights, it is imperative that NGOs appreciate how important a mechanism the

126 L.C. Moss, 'Opportunities for Nongovernmental Organization Advocacy in the Universal Periodic Review Process at the UN Human Rights Council' (2010) 2(1) Journal of Human Rights Practice $122,122$.

127 Human Rights Council Resolution 5/1 (2007) para 15(a) encourages States ' to prepare the information through a broad consultation process at the national level with all relevant stakeholders'.

128 Human Rights Council Resolution 5/1 (2007) states, at para 15(c): 'Additional, credible and reliable information provided by other relevant stakeholders to the universal periodic review which should also be taken into consideration by the council in the review. The Office of the High Commissioner for Human Rights will prepare a summary of such information which shall not exceed 10 pages'.

129 See 'Technical guidelines for the submission of stakeholders' information to OHCHR' <www.ohchr.org/EN/HRBodies/UPR/Pages/TechnicalGuide.aspx > accessed 8 May 1013. These state that submissions should not be longer than 5 pages, but may be accompanied by a more detailed report. The length for submission by coalitions of stakeholders is 10 pages.

130 Brett (n 106) at 11.

131 Moss (n 126) at 122. 
UPR can be in bringing these groups' issues to the attention of the government and the international community. ${ }^{132}$

The adopting of the UN Declaration on the Rights of Indigenous Peoples (UNDRIP) in September 2007 has established the minimum standard for the recognition of the collective rights of indigenous peoples. The UNDRIP therefore needs to be mainstreamed into the work of the UN Human Rights Council as well, particularly within - but not limited to the UPR. ${ }^{133}$

NGOs representing minorities and indigenous peoples were active in highlighting the concerns of their groups and in lobbying States to take these concerns seriously in several phases throughout the UPR process. Some States offered NGOs representing indigenous peoples and minority groups an opportunity to take part in a consultation with the government prior to the completion of the State report, for example Kenya and the US. ${ }^{134}$ Such practice obviously provided these groups with an opportunity to share their concerns with their government and this is an opportunity that many groups would not have had in the absence of the UPR process.

In addition, a number of minority and indigenous peoples' organisations prepared and submitted information as part of stakeholder reports. ${ }^{135}$ Furthermore, a number of such organisations organised side events during the course of the UPR with the aim of highlighting and generating support for their concerns and influencing States to support their point of view through the recommendations they made to States under review. ${ }^{136}$

Minority and indigenous peoples' groups also took part in the plenary session of the Human Rights Council where State reports were adopted. While NGOs are not permitted to speak during the interactive dialogue phase of the UPR they can take the floor during the plenary sessions. Groups which participate during this phase encourage States to accept recommendations and an implementation plan concerning the rights of indigenous peoples. ${ }^{137}$

132 Moss states: "To make the UPR process itself as useful as possible, NGOs should first seek to have States raise their concerns as recommendations to the States under review in the interactive dialogues' by (a) clearly identifying in their written submissions to the process proposed 'recommendations' to the State under review after a clear statement of the underlying facts and concerns; and (b) lobbying UN Member States, either directly or with the assistance of international NGOs in Geneva, to make those recommendations in the dialogues. After the recommendations are listed in the Working Group report, the State under review may be lobbied to accept them both at its Geneva Mission, and by lobbying and public advocacy at home in its national capital." Ibid 149.

133 IWGIA (n 71$)$ at 514.

134 In relation to the mobilisation of indigenous peoples in the United States regarding the UPR process, see the information provided by the International Indian Treaty Council <www.treatycouncil.org/ PDF/UPR_021910WEB.pdf > accessed 10 May 2013.

135 See, for example, IWGIA (n 71) at 516.

136 Ibid.

137 Ibid. 


\subsubsection{Limits on the effectiveness of the UPR with regard to minorities and indigenous groups}

While it is clear that the UPR does present minority and indigenous groups with excellent opportunities to highlight their issues, the process is not perfect. In addition to the general negative aspects of the UPR detailed above, such as the tight time constraints within which the interactive dialogue phase of the process operates and the restrictions placed on States' participation due to financial considerations, other particular dimensions of the UPR could limit its effectiveness specifically as a tool in the promotion and protection of the rights of minorities and indigenous peoples.

One of the major disadvantages of the UPR system is its speed, or indeed, lack thereof. Recommendations made to States are not reviewed until four years later during the next State review. It can, therefore, be difficult to assess the impact of the process in promoting particular human rights issues. For example, if indigenous groups are concerned about impending State-sanctioned construction work which would impact on indigenous lands, then the UPR would not be adequate to deal with such issues. It does not have a 'protective measures' capability which would require the State to refrain from action while the issue of the construction work was assessed by a UN body such as the Human Rights Committee. However, under the framework as it stands, States are provided with the opportunity to comprehensively review the recommendations made by other States and to amend their legislative framework and policy decisions if necessary in order to adequately implement recommendations between reviews. This timeframe can encourage incremental reform in States which may need time to amass the financial and other resources necessary to implement long term changes to their policies and legal regimes. ${ }^{138}$ Rather than a 'quick fix' the UPR provides a foundation for considered review of State actions. Unfortunately, this may not be adequate to address urgent issues affecting minority and indigenous groups.

The second major flaw in the UPR system, which was mentioned above, is that of bias, with the possibility that some States may not critique 'friendly' States or they may not critique them in relation to certain issues for fear that they themselves would be critiqued on the same subjects. This is the major disadvantage of all peerreview systems as no method exists within the UPR to ensure honest and non-biased critique. Therefore, a State with a large indigenous population may be unlikely to critique other States which have a significant indigenous population as this would open it up to scrutiny of its policies and laws in relation to its own indigenous population and perhaps claims of hypocrisy. However, it is interesting to note that Australia did actually make two recommendations in relation to indigenous peoples to Laos in respect of the Lao Hmong people, both of which were accepted. ${ }^{139}$ Similarly, the US made a total of five recommendations to three States concerning indigenous

\footnotetext{
$138 \quad$ See ibid.

139 See 'UPR Info's Database of UPR recommendations and voluntary pledges' < www.upr-info.org/ database/> accessed 30 April 2013.
} 
peoples, ${ }^{140}$ New Zealand made four recommendations to four States ${ }^{141}$ and Canada made nine recommendations to nine States. ${ }^{142}$ However, the potential for bias is where the UN treaty-based system, and indeed, UN Special Procedures, have the upper hand over peer-review mechanisms, with independent committees and individuals making decisions on minority and indigenous peoples. Politics will, to an extent, generally play a part in peer-review processes.

Third, some States may not prioritise minority and indigenous peoples' rights in the domestic sphere and may not attach much importance to these groups when reviewing the reports of other States. So, the effectiveness of the UPR with regard to these groups may depend on them looking outside of their own domestic priorities and focusing on issues relevant to the State under review. However, both the second and third issues are mitigated somewhat by the fact that the UN must submit its own report on each State under review as part of the UPR process and the fact the NGOs can play an active role in the UPR process.

\section{CONCLUSIONS}

The protection of the rights of minorities and indigenous peoples is as important today as ever before. While, prior to the establishment of the UPR, the work of UN treaty bodies in addition to State and shadow reports as well as UN Special Procedures, have been very important in allowing the issues relating to minorities and indigenous peoples to be discussed and reviewed at the international level, there have always been gaps in the protective system. For example, some States ignore minority and indigenous groups when they report to the UN and the UN core human rights treaties are not universally ratified. The UPR is the newest mechanism in the UN human rights regime and because it is as yet in its infancy a definitive conclusion as to its effectiveness in promoting and protecting the rights of minorities and indigenous peoples is not possible. However, some preliminary observations can be made in relation to the efficacy of the process in general and specifically in relation to its framework for dealing with the rights of minorities and indigenous peoples.

It cannot be said that States have been consistent in their response to the UPR in general, or in relation to how they deal with the rights of minorities and indigenous peoples throughout the UPR process. As with all UN human rights monitoring mechanisms State practice has been varied as regards to level of engagement, quality of engagement, and indeed, follow-up, thus, the practical implications in terms of the protection of the rights of minorities and indigenous peoples will be equally varied. Unfortunately, some States which have previously illustrated entrenched

\begin{tabular}{ll}
\hline 140 & Ibid. \\
141 & Ibid. \\
142 & Ibid.
\end{tabular}


positions as regards minorities and indigenous peoples remained steadfast in their stance in spite of lobbying on this issue through the UPR process. The most obvious example of this in the context of the rights of minorities is France, which was open to recommendations on reviewing reservations and declarations it had made in respect of a number of international instruments, for example, the Convention on the Elimination of Discrimination Against Women. ${ }^{143}$ However, it refused ${ }^{144}$ to reconsider its reservation ${ }^{145}$ to Article 27 of the ICCPR concerning minorities, which states that this provision is inapplicable to France as a result of Article 2 of the French Constitution which emphasises equality between all French people, thus precluding the existence of 'minority citizens. ${ }^{146}$ In addition, while accepting a number of recommendations as to the improvement of conditions of the Travelling Community within the State, Ireland rejected recommendations to recognise the Travelling Community as a minority group. ${ }^{147}$

However, some States used the UPR as an opportunity to reopen their consideration of minority and indigenous peoples' rights issues, including the US, which received a number of recommendations with regard to its position on the UNDRIP. ${ }^{148}$ The US had originally voted against the adoption of this instrument in the General Assembly in 2007. ${ }^{149}$ During its UPR review in November 2010 the US undertook to review its stance on the UNDRIP ${ }^{150}$ and subsequently President Obama confirmed the US government's support for the Declaration in December 2010 at the White House Tribal Nations Conference. ${ }^{151}$

Regarding follow up on UPR recommendations, subsequent to the first UPR cycle a number of States set out policies and plans on how to further protect and promote the rights of minorities and indigenous peoples. For example, Romania reinforced its policy on affirmative action in education, ${ }^{152}$ Portugal began preparations for a

\footnotetext{
143 UNGA Res 34/180 (18 December 1979) UN Doc A/RES/34/180.

144 See UNHRC 'Report of the Working Group on the Universal Periodic Review: France' (2013) Add., UN GAOR, Human Rights Council, $8^{\text {th }}$ Sess., UN Doc A/HRC/23/3, 3.

145 France's reservation States: "[i]n the light of article 2 of the Constitution of the French Republic, the French Government declares that article 27 is not applicable so far as the Republic is concerned'.

146 Article (4) of the French Constitution 1958 states: "The Maxim of the Republic shall be "Liberty, Equality, Fraternity"'.

147 See UNHRC 'Report of the Working Group on the Universal Periodic Review: Ireland' (2011) UN GAOR, Human Rights Council, $19^{\text {th }}$ Sess., UN Doc A/HRC/19/9, 16 para 106.33.

148 UNHRC 'Report of the Working Group on the Universal Periodic Review: United States of America' (2011) UN GAOR, Human Rights Council, 16 $6^{\text {th }}$ Sess., UN Doc A/HRC/16/11, 92 para 199, 206.

149 The UNDRIP was adopted by the General Assembly on Thursday 13 September 2007. 144 States voted in favour, four States voted against (Australia, Canada, New Zealand and the United States) with 11 abstentions (Azerbaijan, Bangladesh, Bhutan, Burundi, Colombia, Georgia, Kenya, Nigeria, Russian Federation, Samoa and Ukraine).

150 See (n 148).

151 The text of President Obama's speech on this issue is available at: <www.whitehouse.gov/the-pressoffice/2010/12/16/remarks-president-white-house-tribal-nations-conference $>$ accessed 10 May 2013.

152 See UPR Info (n 108) at 32.
} 
Portuguese Strategy for the Inclusion of Roma Communities, ${ }^{153}$ and Chile developed a policy on indigenous peoples, entitled 'Historical Reunion' which foresees the creation of dialogue between indigenous groups within the State. ${ }^{154}$ While it cannot be proven that these initiatives would not have happened in the absence of the UPR, the process provided a platform for discussion of the needs of minorities and indigenous peoples and an impetus for the formulation of plans to address these needs.

The shortcomings of the UPR process, including bias, tight time restraints during the interactive dialogue phase and tardiness in assessing implementation of recommendations, have been highlighted by many. ${ }^{155}$ However, it is submitted that these are outweighed by the benefits which can accrue to minority and indigenous groups by virtue of this mechanism. One of the most important points in this regard is that minorities and indigenous peoples had found it difficult in the past to obtain a central focus in the UN human rights regime, and were sidelined to an extent in favour of the human rights issues which were subjects of the treaty body system. Because of their status outside of the treaty body system, States were not required to report in an comprehensive manner on their policies and practice with regard to minorities and indigenous peoples and a regular and complete review of State practice in relation to these groups was not always undertaken. Rather, the UN approach to reviewing practice in relation to these groups was undertaken in an ad hoc manner, through a miscellany of apparatus. However, the universality aspect of the UPR is vital as it facilitates a holistic review of State practice and moves the rights of minorities and indigenous peoples into 'mainstream discourse'. 156

NGOs representing minority and indigenous peoples' groups have been cautiously optimistic about the UPR to date, with IWIGA stating that '[a]n initial analysis of the traction gained by indigenous peoples in the UPR indicates limited success.' 157 However, if this early success is to be built on then NGOs representing these groups must recognise and publicise the benefits to be gained through the UPR process. Publicity of the process, and the possible increase in the protection of rights, is needed among minority and indigenous groups so that they are encouraged to utilise it to highlight issues which concern them.

The fact that the Office of the High Commissioner for Human Rights has identified the rights of minorities and indigenous peoples in its UPR reporting template is reflective of the growing importance being attached to these issues within this Office and indeed within the UN in general. The UPR has helped to signal to the international community the fundamental importance of these groups and their rights. Given that the UN human rights monitoring mechanisms to date have to a great extent focussed the majority of their attention on 'mainstream issues such as

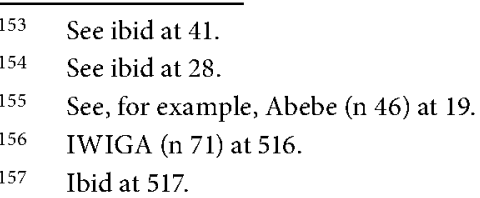


civil and political rights' 158 there is a need to illustrate to all stakeholders how the UPR has created a space for minorities and indigenous peoples in this new review system. Only then can they appreciate the advantages of full and frank engagement with the process and the full potential of the UPR can be tapped for the benefit of these groups. However, the UPR should be seen as being complementary to, rather than as an alternative to, the other established UN mechanisms for the promotion and protection of the rights of minorities and indigenous peoples. While the preUPR approach was quite ad hoc and non-universal, important work had been done by treaty bodies, Special Procedures and NGOs through their shadow reports, in highlighting issues of concern to minorities and indigenous peoples. This article has illustrated how the work of the treaty bodies and Special Procedures can feed into the UPR and it is also envisaged that the UPR recommendations will be referred to by these bodies with increasing frequency in the future to further strengthen the rights of these groups.

$158 \quad$ Ibid. 